\title{
Research on the Mode of Culture Provided for the Aged in China
}

\author{
Hui-ying CHEN \\ School of Arts and Communications \\ Wuhan Polytechnic University \\ Wuhan, Hubei, China \\ chenhy0921@qq.com
}

\begin{abstract}
As one of the countries with the greatest potential in the global aging industry, there are still a lot of places to be improved in china. There are specific needs of the elderly, and examines some problems existing in the present stage of cultural endowment. At last, analysis the four main forms of the existence of China's cultural endowment model, which are family culture pension model, units of cultural endowment model, community cultural pension model and the social institutions of cultural endowment model.
\end{abstract}

Keywords_pension need; pension problem; cultural pension; pension model

\section{INTRODUCTION}

At present, China has become the world's largest population of the elderly, but also the aging population of the fastest growing one of the countries. According to relevant statistics, by the middle of twenty-first Century, China will have more than 500 million people over the age of 60 . It can be predicted that the issue of old-age pension for the elderly is a very important issue in the future development of our country. As one of the countries with the greatest potential in the global aging industry, there are still a lot of places to be improved in china. And the pension industry and related pension model are also related to the vital interests of each person's practical problems, is the need for our society's attention. With the continuous development of China's economy, the aging population in the pension in the process of spiritual and cultural needs should also get more and more attention, the elderly pension culture problem and the modes are various problems still exist. It has become a problem which needs us to analyze and study deeply in our country.

\section{Demand ANALysis of CUltural EndOWMENT FOR THE ELDERLY IN CHINA}

At present, many older people in our country leave their jobs and, at one point, has plenty of free time. Moreover, with China's economic and social development, people's living standard has been greatly improved, in a fixed retirement income under the condition of China's current health care system is also constantly improve, many old people in China can not worry about excessive living problems of their pension process in the. Therefore, more and more elderly people begin to pursue their spiritual needs, and the characteristics of the needs of the elderly demand for cultural endowment include the following three aspects.

\section{A. Demand diversification}

Most elderly people spend their time in family life and some spiritual and cultural life in their retirement. Many elderly people (mostly women) take care of their families, do housework, and help their children bring their children[1]. The specific reasons are the influence of traditional family concept and the busy work of their children. However, family life is only part of the process of providing for the aged, and the vast majority of the elderly still have a certain degree of spiritual and cultural life. Although the elderly life interests are not the same, their focus is different, but also mainly concentrated in, exercise, in the elderly university, travel, reading books newspapers and other aspects, to provide a more rich spiritual and cultural life.

\section{B. The structure of demand stratification}

In the spiritual and cultural needs of the people aged pension level, along with age difference is significantly different, people under the age of 70 , on the cultural endowment demand is mainly reflected in the realization of self-value, eager to play more social value, there is an obvious desire for new culture and ideas acceptance rate faster and more. For older people aged 70 to 80 , they want to have a rich cultural life to participate in, and also have a certain social needs. Older people over the age of 80 are more likely to be respected. In the process of analyzing the cultural endowment pattern of the elderly in our country, we should not neglect the difference of age to the cultural endowment demand.

\section{Demand diversification channels}

The elderly ways in the pursuit of the spiritual and cultural aspects also exist certain differences, the main way to achieve, through their children come to meet the spiritual and cultural aspects, get spiritual and cultural demand of the aged through interaction with friends, through all kinds of original work unit organization activities to meet the spiritual culture, but also a part of the old man is to get spiritual culture through self-study and social satisfaction. It is interesting to note that only a small proportion of elderly people achieve spiritual and cultural needs through the means of society or their communities. 


\section{The Existing Problems of CUltural Endowment IN CHINA}

\section{A. The participation of the elderly in the cultural pension in our country is not high}

Although the elderly are widely accepted cultural endowment pattern, but the elderly pension of cultural participation is still very low, of which nearly $70 \%$ people did not participate in the old university, more than half of the elderly have not participated in the various activities of the entertainment center, only close to $30 \%$ of the elderly respondents participated in some of the elderly interest groups. The reason is that large parts of the elderly have to bear too much family work, and there is not much leisure time to consider their own cultural needs. Also, it is difficult for old people to continue their cultural activities for a long time, while some older people are less interested in themselves. They only watch TV programs for cultural activities every day.

\section{B. The cultural pension development gap between urban and rural areas is larger}

Current urban development level is different, the number of urban and rural construction of various cultural endowment activity center is unbalanced, with the continuous development of economy and society, the differences between urban and rural economic development is also reflected in some developed areas, construction of the elderly activities more and more, and in the economically developed areas, the elderly can participate in the cultural activities are more, in the city to the old-age life provides a rich cultural endowment conditions[2].And in some grass-roots community activities room, the old university, the establishment of the elderly activities center, in some grass-roots areas have been fully used for him, some as storage, and some have even moved for commercial use. At the same time, the level of economic development in different regions is different, and there is a big gap between the investment in the establishment of cultural and pension facilities for the elderly, and many cultural activities of the elderly lack of certain guidance.

\section{The society pays little attention to the cultural endowment}

The whole society pays too much attention to the old people's cultural endowment. China has a long history and culture, filial piety culture has always been an important part of our culture, but in recent years the society is not concerned about the elderly, there will be some negative reports on the elderly[3]. The old people's spiritual and cultural life has lagged behind their material and cultural needs, but many people in society are still not aware of this. The mental level of concern for older people is not high enough.

\section{The mechanism of cultural endowment for the elderly in our country is not perfect}

At present, the lack of cultural endowment in China has hindered the promotion and development of cultural pension to a certain extent. Just rely on some government agencies and social organizations, it is difficult to promote large-scale promotion of cultural endowment mode in our country, is in need of mutual cooperation between the various departments and units, government departments also need further planning. Some of the current system, only pay attention to protect the elderly physical endowment life, in fact, with the development of social economy, we should be aware that the old people's spiritual and cultural demand of the aged is very important in the same way, related mechanism needs to be perfected quickly.

\section{Analysis of the Mode of Cultural ENDOWMENT IN CHINA}

At present, there are mainly four forms of cultural endowment in China: family culture, pension mode, unit culture pension model, community cultural pension model and social institution cultural pension model (as shown in Table 1).

\section{A. Family culture pension model}

It is undeniable that family pension is still the main mode of social support in our country at present. China has a long history and culture, and "filial piety culture" has always been an important part of Chinese traditional culture. Family influence on a person is very large, for each person, more or less want to obtain spiritual needs in family life, the role of the family in the life of the elderly can not be replaced. Especially for the elderly, their family is carrying their hard work for many years of life, the family can let the elderly get a sense of security and satisfaction, so that they feel that there is a place you can rely on, but also have psychological sustenance. With the rapid development of social economy, the social aging degree deepens, the traditional family has always been China's deconstruction also produced changes: children significantly decreased, and with the expansion of the flow range of the population in our country, more and more children will also because of various reasons, such as work, study, marriage is not accompany with my parents. But because of the formation of children's outlook on life, values and the elderly have some differences, they do not understand the parents to accompany in your side psychological needs, there are more and more elderly, elderly people living alone in society. This series of social phenomena are constantly impacting our country. For a long time, the traditional family support mode with children as the core has been formed. For the elderly, it means that they should pay more attention to their own values, pursue their own interests, whether they are children or society, should help the elderly to enrich their daily life. In the interview survey, many old people read their own books, newspapers and periodicals, browse the news on the Internet, play their own interests, and get spiritual and cultural needs in family life.

\section{B. Units of cultural endowment model}

Unit cultural endowment is also an important part of China's cultural endowment model. In today's China, the concept of collective still has a far-reaching impact[3]. Many older people devote most of their lives to the units they work for, and they also want to be spiritually satisfied where they have worked. At present, there are still some government agencies and state-owned enterprises in the development of unit culture pension model in china. For these old cadres and organizations at all levels will often organize a series of activities, whether it is small and large group activities at the grassroots level or, for the aged life more rich and colorful 
experience. Some grass-roots units will also set up some old workers' activities rooms, libraries and other places, so as to provide more recreation options for the elderly who have left their jobs. In addition, some enterprises and institutions will strengthen the ideological construction of retired workers through trade unions and other organizations, and introduce the latest news and policies to the elderly. These old people have certain social service demand, therefore, some units will organize some retired workers to form a number of "supervision team", so that the elderly can have a way to participate in public welfare undertakings, in Zhejiang city of Huzhou Province, there is a group of retired by the organization's "city appearance management supervision team, patrolling the streets so, some uncivilized behavior of public supervision, looking for some government agencies do not place, and put forward suggestions to strengthen the rectification, plays a very important role in rectifying the appearance of the city, purify the social environment, to achieve these old people's spiritual and cultural value of selfsatisfied.

\section{Community cultural pension model}

The model of community cultural support for the aged is based on family support, and exists as an auxiliary form of family cultural support[5]. Communities can provide cultural support for older people living within the boundaries of their management. In the case of some physical condition is not very good for the elderly, community regularly organize personnel door for old people to handle affairs, appliance repair, chat and other services, they can bring great comfort. Community cultural endowment is through the characteristics of the elderly general life range is not big, the community as a platform for cultural endowment, but also convenient for older people to take care of, also in line with the elderly people tend to the nearest pension demand. With the support of the government, the continuous help of society and the keen participation of the elderly, each community has organized a variety of specific forms of cultural support for the elderly. For example, the establishment of community elderly cultural entertainment room, the elderly can participate in here reading, surfing the Internet, playing cards, mutual exchanges and other activities; some communities will form every kind of interest group, can be in the community of like-minded people to organize, facilitate them to communicate with each other, such as dance team, choir etc. form. Community cultural pension is a branch of the community pension model; it absorbs the advantages and feasibility of family culture, pension and social culture pension mode.

\section{The social institutions of cultural endowment model}

Social institution, cultural endowment. The social organization is an integral part of China's pension system, some of the elderly in China, their lack of family care is needed to help complete the old-age life by some for-profit or nonprofit, many pension institutions of the society can provide basic cultural entertainment. With the social and economic development, some pension institutions provide more and more services, but some pension institutions charge higher, not all old.

TABLE I. THE MAIN FORM OF CULTURAL ENDOWMENT PATTERN IN CHINA

\begin{tabular}{|l|l|l|l|}
\hline \multicolumn{1}{|c|}{ Type } & \multicolumn{1}{|c|}{ Features } & \multicolumn{1}{c|}{ Strength } \\
\hline $\begin{array}{l}\text { Family culture } \\
\text { pension model }\end{array}$ & $\begin{array}{l}\text { The elderly live in retirement, live with } \\
\text { their families, or live alone, take care of } \\
\text { their families, and realize the needs of the } \\
\text { elderly }\end{array}$ & $\begin{array}{l}\text { Wlder people are more receptive to } \\
\text { ideas and are more likely to feel secure } \\
\text { and satisfied }\end{array}$ & $\begin{array}{l}\text { The gap between ideas and family members } \\
\text { sometimes causes some family conflicts; the } \\
\text { way of providing for the aged is not scientific }\end{array}$ \\
\hline $\begin{array}{l}\text { Units of cultural } \\
\text { endowment model }\end{array}$ & $\begin{array}{l}\text { Units organize various activities, } \\
\text { encourage the elderly to actively } \\
\text { participate in various matters, and continue } \\
\text { to play the waste heat }\end{array}$ & $\begin{array}{l}\text { Help some older people achieve the } \\
\text { will to continue their personal values }\end{array}$ & $\begin{array}{l}\text { Unit organization activities are difficult, } \\
\text { involving a wide range of participation vary } \\
\text { from person to person }\end{array}$ \\
\hline $\begin{array}{l}\text { Community cultural } \\
\text { pension model }\end{array}$ & $\begin{array}{l}\text { The community provides certain cultural } \\
\text { endowment for the elderly who live within } \\
\text { the scope of their management }\end{array}$ & $\begin{array}{l}\text { In line with the elderly people tend to } \\
\text { the nearest pension needs }\end{array}$ & $\begin{array}{l}\text { The community affairs are complicated, and } \\
\text { the management of the elderly is difficult }\end{array}$ \\
\hline $\begin{array}{l}\text { The social institutions } \\
\text { of cultural } \\
\text { endowment model }\end{array}$ & $\begin{array}{l}\text { Through some for-profit institutions or } \\
\text { non-profit organizations to help complete } \\
\text { the pension life }\end{array}$ & $\begin{array}{l}\text { It is convenient for scientific } \\
\text { management of elderly people's life } \\
\text { support; it is easy to organize various } \\
\text { kinds of activities }\end{array}$ & $\begin{array}{l}\text { Each pension institution has a large gap in fees } \\
\text { and a large difference in conditions, and the } \\
\text { difficulty of changing the concept of the } \\
\text { elderly is higher }\end{array}$ \\
\hline
\end{tabular}

\section{CONCLUSION}

According to China's existing cultural endowment mode, combined with the analysis of the demand of the elderly in China on the cultural endowment, China's future development will be the development of culture endowment pattern model presents various pension models with each other and complement each other. At present, the mode of family support is still the most popular way for the elderly in China[6]. According to the relevant research, the proportion of elderly people living alone in China will continue to rise in the future. To support the family pension model, we need to combine with other pension mode, in order to ensure that the elderly of the elderly in our country can live in a safe and healthy life. According to the survey of the elderly in China for old-age life in the spiritual and cultural needs is more valued, personal interests and activities of the personal demand, the need for respect and social demand, and the way of the elderly pension demand culture and focus on the elderly, children, friends. Therefore, the development of China's cultural endowment model should greatly enhance the importance of the community and the community of elderly people in the cultural endowment activities. Social institutions and community should strengthen their own professional for the elderly pension problems, and provide a richer cultural endowment activity, also can be more effective to provide more convenient demand for social demand and interest in the cultural activity 
of the elderly in old age. In the future, the elderly can carry out a variety of individual choices in various cultural endowment patterns, providing each of the elderly with their own cultural endowment model, which is the hope of society, family and the elderly.

\section{REFERENCES}

[1] FANG Ai-qing, WANG Hao. Analysis on the Basic Connotation, Contemporary Value and Paths of Cultural Care for the Aged[J]. Journal of Jianghan University(Social Science Edition),2015,32(4):34-37

[2] Tang Xiao-ying. Exploration of community cultural endowment in China from the perspective of traditional culture [J].Journal of
Northwestern Polytechnical University (Social Sciences), 2011, 31 (2): 44-48

[3] Zhong chun-yang. Analysis of the development path of community cultural endowment $[\mathrm{J}]$.Journal of Sichuan Administration College, 2012, (1):79-81

[4] MA Hong-xia. Research on the Current Situation of the Urban Community Sports Culture Endowment Health Services Research [J].2016, $33(2): 87-90$

[5] CUI Zhang-li. Study on the problems and Countermeasures of community support for the aged in China[J].Management World, 2009,(7):178-181

[6] Zhang Di, Xiang Ying, Du Meng-shu. A survey of the demand for elderly education in Hangzhou under the background of cultural support and its influencing factors [J].Industrial \& Science Tribune, 2017, $6(6): 129-130$ 